\title{
Validity of polyethyleneglycol in the study of the total pancreatic secretion in man after stimulation by secretin, pancreozymin, or food
}

\author{
H. WORNING \\ From the Medical Department and the Central Laboratory, the Blegdamshospital, \\ Copenhagen, Denmark
}

\begin{abstract}
EDITORIAL COMMENT Calculations of rate of flow can be misleading on account of incomplete mixing or distribution across the transverse section of the intestine. This error is minimized when there is increased muscular activity.
\end{abstract}

Experimental studies in anaesthetized animals have shown that calculation of the intestinal flow by means of infusion of unabsorbable markets may be misleading to a varying degree (Jacobson, Bondy, Broitman, and Fordtran, 1963; Worning and Amdrup, 1965; Worning, Amdrup, and Henriksen, 1966).

It is the aim of the present study to define whether the intestinal flow, i.e., the amount of fluid which during a given time passes a given section of the intestine, might be determined in the intact human intestinal tract by the marker technique, thereby obtaining an expression of the rate of secretion of pancreatic enzyme after stimulation of the pancreatic secretion by secretin, pancreozymin, or food.

\section{METHODS}

The duodenum was intubated by means of a double tube composed of two polyvinyl tubes (external/internal diameter $2 \cdot 3 / 2 \cdot 1 \mathrm{~mm}$.). The terminal $5 \mathrm{~cm}$. of the longer tube was provided with eight perforations in the wall; the shorter tube was tied to the longer one 10 to $20 \mathrm{~cm}$. orally to the perforations. When the tip of the longer tube reached the ligament of Treitz, and that of the shorter was at least $5 \mathrm{~cm}$. distally to the pylorus, the tubes were fixed to the cheek of the subject. In all cases the position of the tubes was checked radiologically.

Polyethyleneglycol 4000 (P.E.G.), dissolved in physiological saline, served as marker.

Throughout the whole experiment the marker solution was infused at a constant rate through the shorter tube

'Aided by grants from the Foundation Til Lagevidenskabens Fremme and P. Carl Petersen's Foundation. while the intestinal content was simultaneously recovered by simple siphonage through the longer tube. The infusion rate varied between 0.6 and $2.5 \mathrm{ml} . / \mathrm{min}$. in the different experiments.

After a preliminary period covering 20 to 30 minutes, the pancreatic secretion was stimulated by secretin (Lilly or Vitrum), $1 \mathrm{u} / \mathrm{kg}$. intravenously, or by pancreozymin (Boots or Cecekin, Vitrum), $1 \mathrm{u} / \mathbf{k g}$. intravenously, or by an orally administered fluid meal consisting of $45 \mathrm{~g}$. of skimmed milk powder supplemented by corn oil and $20 \mathrm{~g}$. glucose, all dissolved in $300 \mathrm{ml}$. of water.

Subsequently the intestinal content was aspirated for 60 or 80 minutes subdivided into 20 -minute intervals.

In the cases in which secretin or pancreozymin were used as stimulants, the gastric juice was aspirated by means of intermittent, mechanical suction at negative pressure of 50 to $100 \mathrm{~mm} . \mathrm{Hg}$ through a separate tube inserted distally into the stomach.

The aspirated intestinal content was measured, and the concentrations of P.E.G. and of amylase were determined in the individual aspirates. Polyethyleneglycol was determined according to Hyden's method (1955), and $\alpha$-amylase was determined according to Dahlqvist's method (1962) with minor modifications (Worning and Müllertz, 1966).

Using the following symbols, rate of infusion of marker solution $=\mathrm{v} \mathrm{ml}$./min., concentration of marker in the solution $=\mathrm{a} \mathrm{mg} . / \mathrm{ml}$., volume aspirated during the time $\mathrm{t}=\mathrm{r} \mathrm{ml}$., concentration of marker in $r=b \mathrm{mg} . / \mathrm{ml}$., concentration of $\alpha$-amylase in $r=c U . / m l$, the integrated intestinal flow (I.I.F.) $=$ the volume passing the site of aspiration in a given time $t$ can be calculated as (I.I.F.) $=\mathrm{v} \mathrm{t} \mathrm{a} / \mathrm{b} \mathrm{ml}$.

The integrated endogenous intestinal flow is during the same period =(I.I.F.) - $\mathrm{v} \mathrm{t} \mathrm{ml}$. The recovery of marker is calculated as $100 \mathrm{r} \mathrm{b} / \mathrm{v} \mathrm{t}$ a per cent, and the total secretion of amylase as (I.I.F.) c. 
TABLE I

RECOVERY OF INFUSED MARKER (P.E.G.) AS PERCENTAGES OF INFUSED AMOUNTS IN THE FASTING STATE AND AT DIFPERENT INTERVALS AFTER STIMULATION OF THE PANCREATIC SECRETION

\begin{tabular}{|c|c|c|c|c|c|c|c|}
\hline \multirow{2}{*}{ Stimulan } & & \multicolumn{6}{|l|}{ Period } \\
\hline & & Fasting & $\begin{array}{l}0-20 \\
\text { Minutes }\end{array}$ & $\begin{array}{l}20-40 \\
\text { Minutes }\end{array}$ & $\begin{array}{l}40-60 \\
\text { Minutes }\end{array}$ & $\begin{array}{l}\text { 60-80 } \\
\text { Minutes }\end{array}$ & $\begin{array}{l}80 \\
\text { Minutes }\end{array}$ \\
\hline Secretin & $\begin{array}{l}n \\
\text { Mean } \\
\text { Range }\end{array}$ & & $\begin{array}{l}9 \\
32 \cdot 4 \\
0-100\end{array}$ & $\begin{array}{c}9 \\
13 \cdot 3 \\
0.54\end{array}$ & $\begin{array}{l}9 \\
8 \cdot 6 \\
0-26\end{array}$ & $\begin{array}{c}9 \\
17.9 \\
0-57\end{array}$ & $\begin{array}{c}9 \\
18 \cdot 1 \\
4-41\end{array}$ \\
\hline $\begin{array}{l}\text { Pancreo- } \\
\text { zymin }\end{array}$ & $\begin{array}{l}\text {-Mean } \\
\text { Range }\end{array}$ & & $\begin{array}{c}8 \\
15.9 \\
2-45\end{array}$ & $\begin{array}{c}8 \\
13 \cdot 0 \\
0-45\end{array}$ & $\begin{array}{c}8 \\
12 \cdot 0 \\
0-28\end{array}$ & $\begin{array}{l}6 \\
34 \cdot 2 \\
0-100\end{array}$ & $\begin{array}{c}8 \\
18 \cdot 1 \\
6-35\end{array}$ \\
\hline $\begin{array}{l}\text { Standard } \\
\text { meal }\end{array}$ & $\begin{array}{l}\text { d } \mathbf{n} \\
\text { Mean } \\
\text { Range }\end{array}$ & & $\begin{array}{l}15 \\
29 \cdot 5 \\
0-74\end{array}$ & $\begin{array}{l}15 \\
16 \cdot 1 \\
0-48\end{array}$ & $\begin{array}{l}15 \\
23 \cdot 7 \\
4-75\end{array}$ & $\begin{array}{l}15 \\
22 \cdot 3 \\
0-79\end{array}$ & $\begin{array}{l}16 \\
21 \cdot 4 \\
3-53\end{array}$ \\
\hline All & $\begin{array}{l}\text { n } \\
\text { Mean } \\
\text { Range }\end{array}$ & $\begin{array}{l}19 \\
22 \cdot 5 \\
3-68\end{array}$ & $\begin{array}{l}32 \\
27 \cdot 0 \\
0-100\end{array}$ & $\begin{array}{l}32 \\
14 \cdot 6 \\
0-54\end{array}$ & $\begin{array}{l}32 \\
16 \cdot 6 \\
0-75\end{array}$ & $\begin{array}{l}30 \\
23 \cdot 3 \\
0-100\end{array}$ & $\begin{array}{l}33 \\
19 \cdot 8 \\
3-53\end{array}$ \\
\hline
\end{tabular}

$\mathbf{n}=$ number of observations

MATERIAL

The examinations were carried out by a uniform technique on 33 inpatients; secretin was used as stimulant on nine occasions (in eight subjects), pancreozymin on eight occasions (in the same eight subjects); a fluid meal composed of skimmed milk powder with corn oil and glucose dissolved in water served as stimulant on 16 occasions.

\section{RESULTS}

RECOVERY OF INFUSED MARKER Table I illustrates the recovery of marker substance, recorded as mean value and observed ranges. The apparently different mean recoveries following one or the other stimulant were not statistically significant, nor did recovery alter significantly during the period of aspiration. The individual variations of recovery were quite appreciable and, within the individual subject, recovery might vary considerably from one 20 minute period to the next. With the technique used here, recovery amounted merely to about $20 \%$.

CALCUlated INTESTINAL Flow Table II records the mean values for the integrated endogenous intestinal flow obtained in the four 20-minute periods following stimulation of the pancreatic secretion. Figures represent observations obtained exclusively in subjects without symptoms or signs of gastrointestinal disorders. Figure 1 shows the equivalent individual values. Irrespective of the stimulant used, the calculated integrated endogenous intestinal flow showed considerable inter-period variations in the individual subject. The inter-subject variations were marked, especially after stimulation
TABLE II

CALCULATED INTEGRATED ENDOGENOUS INTESTINAL FLOW AT DIFFERENT PERIODS AFTER STIMULATION OF THE PANCREATIC SECRETION (ML./20 MIN.)

\begin{tabular}{|c|c|c|c|c|c|}
\hline \multirow[b]{2}{*}{ Stimulant } & & \multicolumn{4}{|l|}{ Period } \\
\hline & & $\begin{array}{l}0-20 \\
\text { Minutes }\end{array}$ & $\begin{array}{l}20-40 \\
\text { Minutes }\end{array}$ & $\begin{array}{l}40-60 \\
\text { Minutes }\end{array}$ & $\begin{array}{l}60-80 \\
\text { Minutes }\end{array}$ \\
\hline Secretin & $\begin{array}{l}\text { n } \\
\text { Mean }\end{array}$ & $\begin{array}{c}5 \\
117.0\end{array}$ & $\begin{array}{c}5 \\
187.6\end{array}$ & $\begin{array}{c}4 \\
129 \cdot 8\end{array}$ & $\begin{array}{c}6 \\
147 \cdot 5\end{array}$ \\
\hline $\begin{array}{l}\text { Pancreo- } \\
\text { zymin } \\
\text { Standard } \\
\text { meal }\end{array}$ & $\begin{array}{l}\mathbf{n} \\
\text { Mean } \\
\text { n } \\
\text { Mean }\end{array}$ & $\begin{array}{c}5 \\
116 \cdot 2 \\
6 \\
93 \cdot 6\end{array}$ & $\begin{array}{c}4 \\
124 \cdot 8 \\
6 \\
226 \cdot 0\end{array}$ & $\begin{array}{c}3 \\
91 \cdot 3 \\
6 \\
124 \cdot 2\end{array}$ & $\begin{array}{c}2 \\
56.5 \\
5 \\
117.8\end{array}$ \\
\hline
\end{tabular}

$\mathbf{n}=$ number of observations

by secretin or pancreozymin (Fig. 1). Following secretin, the intestinal flow was, on an average and in all subjects, calculated to the highest value in the second 20-minute period (Table II, Fig. 1A). Mean values in the periods $40-60$ and $60-80$ minutes after secretin were higher than that recorded for the initial 20-minute period (Table II).

Only small differences between the integrated endogenous intestinal flow following secretin and pancreozymin were apparent in the initial two periods. Following stimulation by secretin or food, the total would, on an average, be about $500 \mathrm{ml} . / 80$ min.; after stimulation by pancreozymin it would be $400 \mathrm{ml} . / 80 \mathrm{~min}$.

CALCUlated SECRETION OF AmYlase Table III records the mean values of the calculated total secretions of amylase during 20-minute intervals, expressed in kilounits $(\mathrm{kU})$. The table includes 


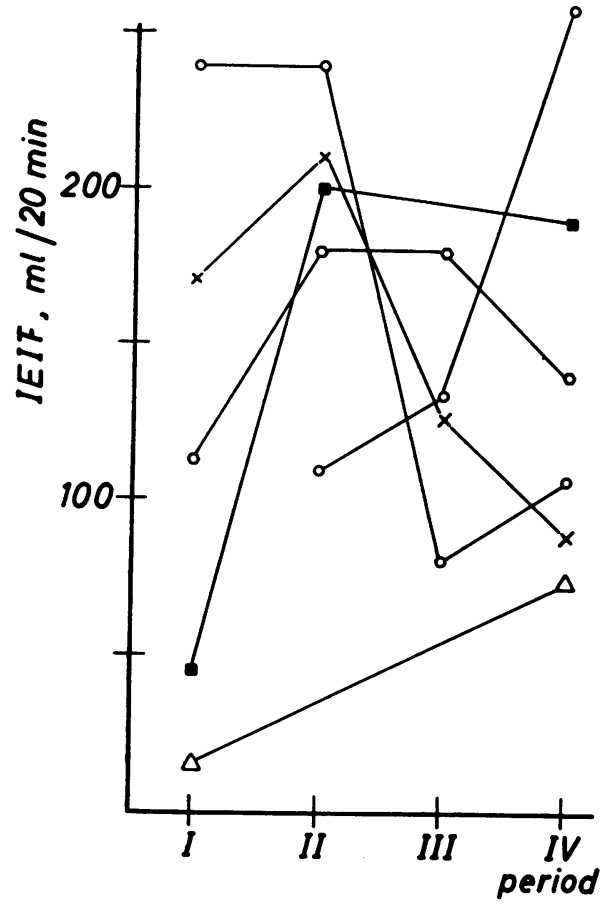

FIG. $1 \mathrm{a}$

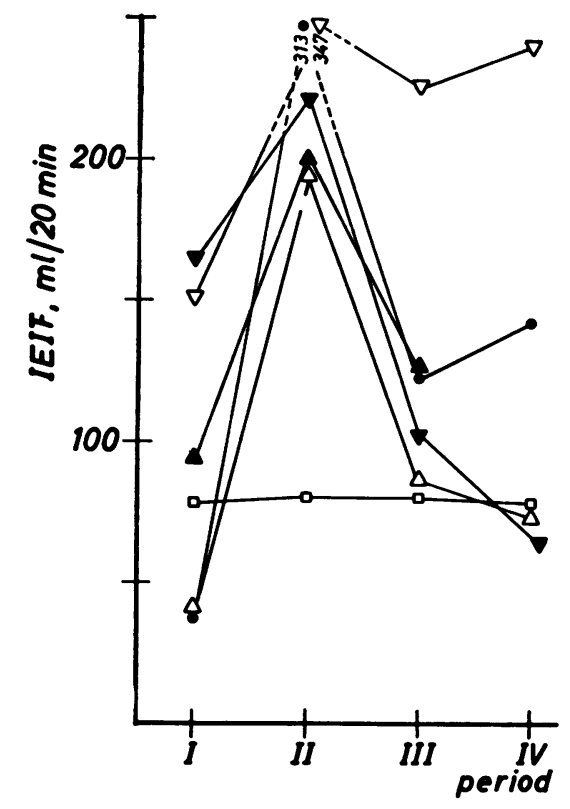

FIG. 1c

FIG.1. The integrated endogenous intestinal flow(I.E.I.F.), calculated on the basis of the concentration of marker in aspirates in four 20-minute periods after stimulation of the pancreatic secretion by $(A)$ secretin (Lilly), $(B)$ pancreozymin (Boots), (C) food.

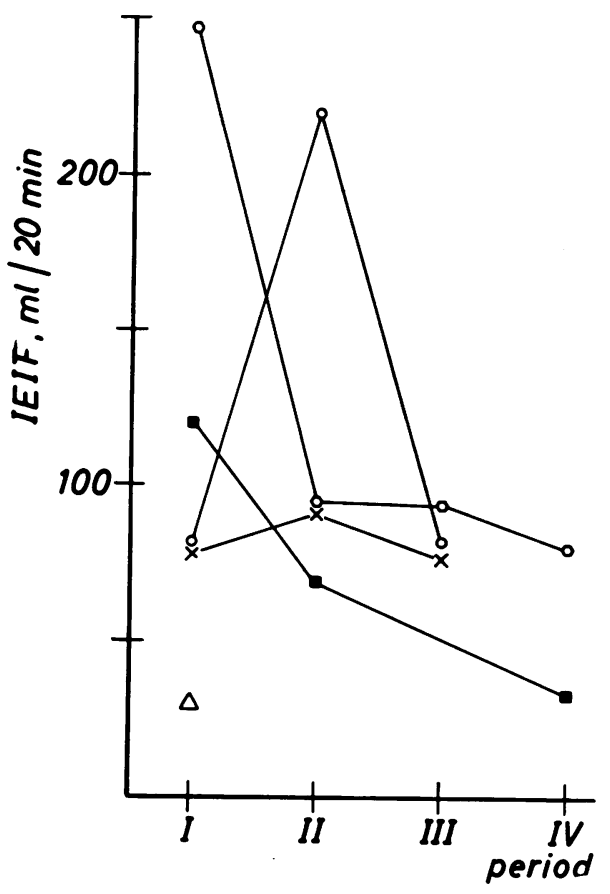

FIG. $1 \mathrm{~b}$

values exclusively obtained in subjects without gastrointestinal disorders. The equivalent individual values are seen in Figure 2. Variations between amounts secreted in the different periods in the individual subjects, as well as variations from one subject to another, were appreciable here too. In general the calculated values for secretion of amylase varied in parallel with that for the integrated endogenous intestinal flow (Figs. 1 and 2). The mean values in the two initial periods were nearly identical following secretin and pancreozymin, being more excessive after a meal (Table III).

\section{TABLE III}

CALCULATED SECRETION OF AMYLASE IN DIFFERENT PERIODS AFTER STIMULATION OF THE PANCREATIC SECRETION (KU IN 20 MIN.)

\begin{tabular}{llllll} 
Stimulant & \multicolumn{3}{l}{ Period } & & \\
\cline { 2 - 6 } & $\begin{array}{l}\text { 0-20 } \\
\text { Minutes }\end{array}$ & $\begin{array}{l}20-40 \\
\text { Minutes }\end{array}$ & $\begin{array}{l}40-60 \\
\text { Minutes }\end{array}$ & $\begin{array}{l}60-80 \\
\text { Minutes }\end{array}$ \\
\hline Secretin n & 5 & 5 & 3 & 6 \\
& Mean & $12 \cdot 150$ & $13 \cdot 852$ & $8 \cdot 463$ & $12 \cdot 122$ \\
Pancreo- n & 5 & 4 & 2 & 2 \\
zymin & Mean & $10 \cdot 100$ & $12 \cdot 765$ & $14 \cdot 150$ & $6 \cdot 265$ \\
Standard n & 6 & 6 & 6 & 5 \\
meal & Mean & $14 \cdot 360$ & $26 \cdot 440$ & $15 \cdot 964$ & $16 \cdot 022$
\end{tabular}

$\mathrm{n}=$ number of observations 


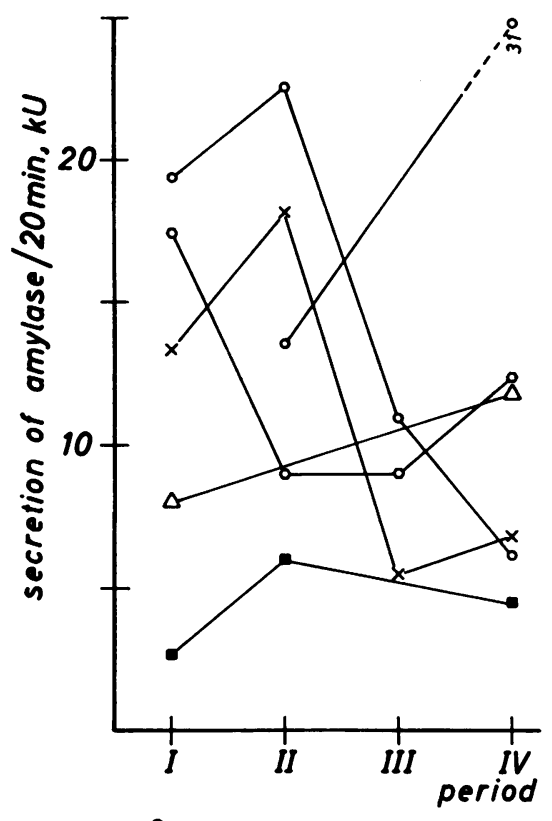

FIG. 2a

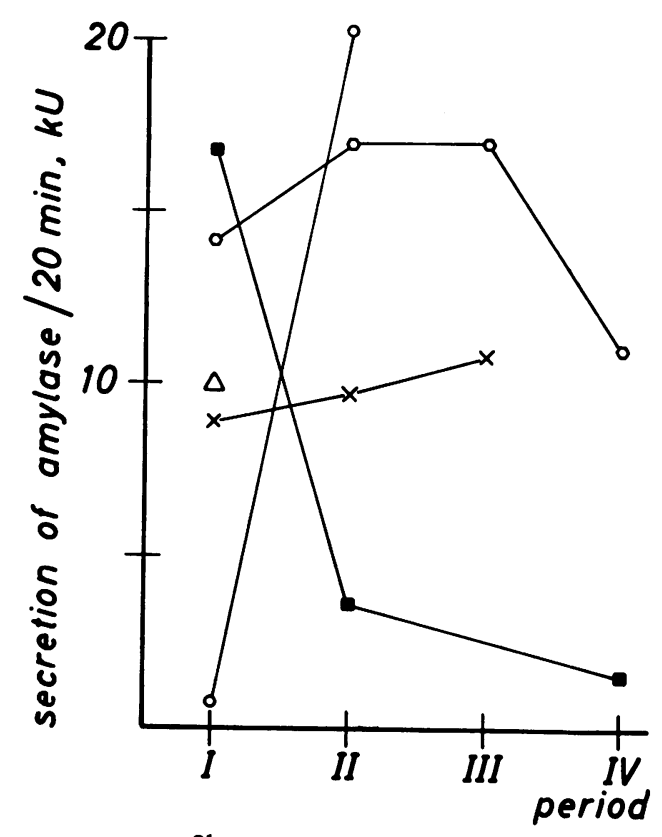

FIG. $2 b$

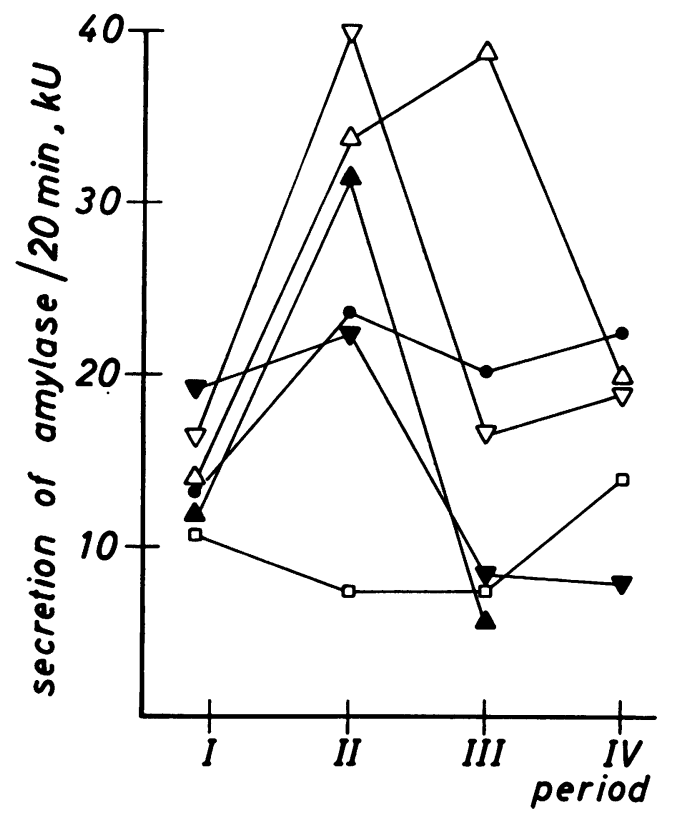

FIG. 2c

FIG. 2. The calculated secretion of amylase in four 20-minute periods after stimulation of the pancreatic secretion by $(A)$ secretin (Lilly), (B) pancreozymin (Boots), (C) food.
In one subject, the integrated endogenous intestinal flow and the total secretion of amylase following stimulation by secretin was examined on two successive days. The reproducibility was very poor (Figs. 1A and 2A).

\section{DISCUSSION}

According to the recovery experiments, quantitative recovery of the intestinal contents represents the exceptions when the technique discussed here was used. The fluctuating recovery in the individual subject indicated that the part of the intestinal flow to be aspirated varied considerably from one period to the next.

The calculated values for intestinal flow and pancreatic enzyme secretion were in many respects incompatible with the present knowledge of the pancreatic function.

Numerous clinical investigations have shown the secretin-released secretion, estimated by means of aspiration from the distal part of the duodenum, to be most intense during the initial 10 to 20 minutes following the injection, after which it gradually subsides (Voegtlin, Greengard, and Ivy, 1934; Ågren and Lagerlöf, 1936; Diamond, Siegel, Gall, and Karlen, 1939; Lagerlöf, 1942; Dornberger, Comfort, Wollaeger, and Power, 1948; Pfeffer, Stephenson, Jr., and Hinton, 1952; Dreiling, 1955; Burton, Evans, Harper, Howat, Oleesky, Scott, and 
Varley, 1960; Dreiling and Janowitz, 1962; Lagerlöf, Ek and Nyberg, 1962; Correia and Barros, 1963; Christensen, 1963). Cases with the largest aspirates in the second 20-minute period following the injection of secretin have been recorded (Lake, 1947; Cathalan, Charmot, and Pujo, 1961; Gülzow and Arendt, 1964), but values in the periods $40-60$ and 60-80 minutes exceeding those obtained in the initial 20 minutes have never been observed.

The mean value for the calculated integrated endogenous intestinal flow following secretin (500 $\mathrm{ml} . / 80 \mathrm{~min}$.) exceeded by far the volumes aspirated from the distal duodenum following stimulation by secretin in a similar dose. Dreiling (1955) recorded a mean value of $200 \mathrm{ml} . / 80 \mathrm{~min}$., and Rosenberg, Friedland, Janowitz, and Dreiling (1966) recorded a value of $230 \mathrm{ml} . / 80 \mathrm{~min}$. Higher values have not been recorded.

The lack of differences between mean values for the integrated endogenous intestinal flow and amylase secretion in the initial two periods after secretin and pancreozymin are in contradistinction to the physiological action of secretin as a specific stimulant to the secretion of fluid and bicarbonate (Janowitz and Dreiling, 1962) and pancreozymin as a specific stimulant to the secretion of enzyme (Harper, Blair, and Scratcherd, 1962). The decreasing values for the integrated endogenous intestinal flow and, to a minor degree of amylase secretion, in the later periods following pancreozymin are in fair accord wtih the short time of action of injected pancreozymin (Werner and Mutt, 1954; Dreiling and Janowitz, 1962; Hanscom and Littman, 1963).

The results obtained after stimulation by a meal are conflicting and difficult to interpret.

Hunt and MacDonald (1954) and Borgström, Dahlqvist, Lundh, and Sjövall (1957) have shown the rate of gastric emptying after meals of the type and size used here to be fairly constant except for the initial period, when the rate of emptying is slower.

Pincus, Thomas, Hausman, and Lachman (1948), Annis and Hallenbeck (1952), and Henriksen and Worning (unpublished data) demonstrated in dogs that the pancreatic secretion of fluid as well as of enzyme increased immediately after food, a feature also seen in human subjects suffering from pancreatic fistula (Hölsti, 1913; Mocquot, Joltrain, and Landat, 1933; Turai, Vintila, Cosmulesco, Soare, and Stanesco, 1961). After the initial rise, however, the secretion remains fairly constant for a long time.

Worning and Müllertz (1966) observed that the concentrations of different pancreatic enzymes in aspirates from the human duodenum were highest in the initial 20 minutes after ingestion of a fluid meal. In the subsequent hour the concentrations remained constant at a lower level.
Thus, there is every possibility that the endogenous flow through the duodenum, and the secretion of enzyme from the pancreas, increase from the first to the second 20-minute period after intake of food and then remain constant at least for an hour.

In the initial two periods, the calculated values for the integrated endogenous intestinal flow and for secretion of amylase were on an average (Tables II and III) and in nearly all subjects (Figs. 1C and 2C) in fair accord with the expected values. In the same two periods the inter-subject variations were limited. In the last two periods the inter-subject variations and the discrepancies between calculated and expected values were considerable. In one subject, the calculated values for the integrated endogenous intestinal flow and for amylase secretion differed markedly from values obtained in the other subjects (Figs. 1C and 2C).

Irrespective of the stimulant applied discrepancies between the calculated and the expected integrated endogenous intestinal flow were seen. If correct values are to be obtained with the technique used here regurgitation to the stomach of the infused marker must not take place. Furthermore, a uniform mixing of the marker in the intestinal contents is a necessary prerequisite.

The gastric aspirates obtained after stimulation by secretin or pancreozymin were not analysed for P.E.G. Thus, regurgitation to the stomach cannot be excluded. Lagerlöf (1942) and Dreiling and Hollander (1948) observed, however, that permanent aspiration of the duodenal contents prevented regurgitation to the stomach.

It has already been demonstrated (Worning and Amdrup, 1965) that infused marker is not uniformly distributed over the transverse section of the intestine, and this incomplete mixing of the infused marker in the intestinal contents is probably the main reason for the incorrect flow calculations. In general, the results obtained after ingestion of a meal were in better accord with the expected values than were the results obtained after stimulation by secretin or pancreozymin. This may be due to a more intense duodenal motility during digestion of the meal resulting in a more uniform mixing of the infused marker in the intestinal contents.

It is evident from the results obtained that the technique used here, involving permanent infusion of a nonabsorbable marker proximally into the intestine, fails to determine with sufficient accuracy the endogenous intestinal flow in the intact, human intestinal canal after stimulation of the pancreatic secretion by secretin or pancreozymin. Consequently, determination of the rate of enzyme secretion from the pancreas during a given period following stimulation is impossible. 
The results obtained after ingestion of a meal were probably more reliable. The pronounced intersubject variations in the later periods and the low values in one of the subjects indicate that misleading results were obtainable even after ingestion of a meal.

In the single subject it can hardly be decided whether the intestinal flow is estimated with sufficient accuracy or with a considerable error. Thus, the technique is not applicable for determination of the secretion rates of pancreatic enzymes in the single subject.

\section{SUMMARY}

Using infusion of a non-absorbable marker proximally into the duodenum, an attempt has been made to determine the intestinal flow, i.e., the volume of fluid passing a definite intestinal section within a definite period, together with the coincident total amylase secretion from the pancreas after stimulation of the pancreatic secretion by secretin, pancreozymin, or food.

The calculated intestinal flow and the calculated values representing the total amylase secretion deviate appreciably from the expected values in the experiments using secretin or pancreozymin as stimulant.

In general, the deviations from the expected values were less pronounced after ingestion of a meal, but even here some of the results were misleading.

The technique used here has failed to provide a sufficiently exact calculation of the pancreatic secretion of amylase in a single subject.

\section{REFERENCES}

Ågren, G., and Lagerlöf, H. (1936). The pancreatic secretion in man after intravenous administration of secretin. Acta med. scand., 90, 1-29.

Annis, D., and Hallenbeck, G. A. (1952). The effects of partial gastrectomy on canine external pancreatic secretion. Surgery, 31, 517-527.

Borgström, B., Dahlqvist, A., Lundh, G., and Sjövall, J. (1957). Studies of intestinal digestion and absorption in the human. J. clin. Invest., 36, 1521-1536.

Burton, P., Evans, D. G., Harper, A. A., Howat, H. T., Oleesky, S., Scott, J. E., and Varley, H. (1960). A test of pancreatic function in man based on the analysis of duodenal contents after administration of secretin and pancreozymin. Gut, 1, 111-124.

Cathalan, G., Charmot, G., and Pujo, P. (1961). Etude statistique du dosage des bicarbonates, de l'activité lipasique dans le liquide duodénal du sujet normal, avant et après injection de sécretine. Presse méd., 69, 1911-1912.

Christensen, B. C. (1963). Studies on the secretin test. Acta med. scand., 173, 315-327.

Correia, J. P., and Barros, F. (1963). Untersuchungen zur Prüfung der Pankreasfunktion mit Sekretin und Pankreozymin. $Z$. Gastroent., 1, 236-249.

Dahlqvist, A. (1962). A method for the determination of amylase in intestinal content. Scand. J. clin. Lab. Invest., 14, 145-151.

Diamond, J. S., Siegel, S. A., Gall, M. B., and Karlen, S. (1939). The use of secretin as a clinical test of pancreatic function. Amer. J. dig. Dis., 6, 366-372.
Dornberger, G. R., Comfort, M. W., Wollaeger, E. E., and Power, M. H. (1948). Pancreatic function as measured by analysis of duodenal contents before and after stimulation with secretin. Gastroenterology, 11, 701-713.

Dreiling, D. A. (1955). The technique of the secretin test: normal ranges. J. Mt. Sinai Hosp., 21, 363-372.

$\longrightarrow$, and Hollander, F. (1948). Studies in pancreatic function. 1. Preliminary series of clinical studies with secretin test. Gastroenterology, 11, 714-729.

- and Janowitz, H. D. (1962). The measurement of pancreatic secretory function. In Ciba Foundation Symposium on the Exocrine Pancreas edited by A. V. S. de Reuck and M. P. Cameron, pp 225-258. Churchill, London.

Gülzow, M., and Arendt, R. (1964). Zur Reproduzierbarkeit von Pankreassekretionstesten. Dtsch.Z.Verdau.-u. Stoffwechselkr. 24, 34-43.

Hanscom, D. H., and Littman, A. (1963). Dose-response relationships to pancreozymin in normal subjects and patients with chronic pancreatitis. Gastroenterology, 45, 209-214.

Harper, A. A., Blair, E. L., and Scratcherd, T. (1962). The distribution and physiological properties of pancreozymin. In Ciba Foundation Symposium on the Exocrine Pancreas, edited by A. V. S. de Reuck and M. P. Cameron, pp. 168-185. Churchill, London.

Hunt, J. N., and MacDonald, I. (1954). The influence of volume on gastric emptying. J. Physiol. (Lond.), 126, 459-474.

Hyden, S. (1955). A turbidometric method for the determination of higher polyethyleneglycols in biological materials. Ann. Agr. Coll. (Sweden), 22, 139-145.

Hölsti, O. (1913). Beitrag zur Kenntnis der Pankreassekretion beim Menschen. Dtsch. Arch. klin. Med., 111, 48-92.

Jacobson, E. D., Bondy, D. C., Broitman, S. A., and Fordtran, J. S. (1963). Validity of polyethylene glycol in estimatir.g intestinal water volume. Gastroenterology, 44, 761-767.

Janowitz, H. D., and Dreiling, D. A. (1962). The pancreatic secretion of fluid and electrolytes. In Ciba Foundation Symposium on the Exocrine Pancreas, edited by A. V. S. de Reuck and M. P. Cameron, pp. 115-137. Churchill, London.

Lagerlöf, H. O. (1942). Pancreatic function and pancreatic disease studied by means of secretin. Acta med. scand., suppl. 128.

- Ek, S. Y., and Nyberg, A. (1962). The duodenal secretion in man as a function of secretin dose and secretin inactivation. Gastroenterology, 43, 174-180.

Lake, M. (1947). Diagnostic value of secretin test, including report of 19 operated or autopsied cases, with anatomical studies of the pancreas. Amer. J. Med., 3, 18-30.

Mocquot, Joltrain, E., and Landat, (1933). Abcés du pancréas d'origine colibacillaire. Fistule avec écoulement du suc pancréatique. Étude des sécrétions externes et internes du pancréas. Rev. Méd. (Paris), 50, 231-245.

Pfeffer, R. B., Stephenson, H. E. Jr., and Hinton, J. W. (1952). The effect of thoracolumbar sympathectomy and vagus resection on pancreatic function in man. Ann. Surg., 136, 585-592.

Pincus, I. J., Thomas, J. E., Hausman, D., and Lachman, P.O. (1948). Relationship between the pH of the duodenal content and pancreatic secretion. Proc. Soc. exp. Biol. (N.Y.), 67, 497-501.

Rosenberg, I. R., Friedland, N., Janowitz, H. D., and Dreiling, D. A. (1966). The effect of age and sex upon human pancreatic secretion of fluid and bicarbonate. Gastroenterology, 50, 191-194.

Turai, I., Vintila, I., Cosmulesco, I., Soare, M., and Stanesco, R. (1961). Recherches concernant la fonction externe du pancréas. Chez un ancien réséqué gastriqué, porteur d'une fistule pancréatique post-traumatique récente. Arch. Mal. Appar. dig., 50, 1357-1371.

Voegtlin, W. L., Greengard, H., and Ivy, A. C. (1934). The response of canine and human pancreas to secretin. Amer. J. Physiol., 110, 198-224.

Werner, B., and Mutt, V. (1954). The pancreatic response in man to the injection of highly purified secretin and of pancreozymin. Scand. J. clin. Lab. Invest., 6, 228-236.

Worning, H., and Amdrup, E. (1965). Experimental studies on the value of the reference substances polyethyleneglycol. bromsulphthalein, and ${ }^{51}$ - $\mathrm{Cr}$ as indicators of the fluid content in the intestinal lumen. Gut, 6, 487-493.

,-- , and Henriksen, F. W. (1966). Experimental studies of the intestinal flow using ${ }^{51}-\mathrm{Cr}$ as indicator. Scand. J. Gastroent., 1, 111-120.

- , and Mullertz, S. (1966). $p H$ and pancreatic enzymes in the human duodenum during digestion of a standard meal. Ibid., 1, 268-283. 